\title{
TEOLOGIE EN EKOLOGIE
}

\section{B J ENGELBRECHT}

1. Ekologie is tradisioneel ' $n$ onderdeel van die biologie wat handel oor die verhouding van lewende organismes en hulle omgewing en die daaruit voortvloeiende lewenspatrone. Eintlik behoort alle "-logie-" woorde op die wetenskap wat 'n bepaalde saak bestudeer, te slaan, maar soos met 'n paar ander woorde beteken ekologie ook die objek, die saak self wat bestudeer word. So word dikwels gesê: As dit of dat gedoen word, sal ons die ekologie versteur. In hierdie artikel gebruik ek die woord ekologie veral in hierdie laaste sin, dit wil sê eerder as werklikheid en nie soseer as wetenskap nie. Trouens, ook as wetenskap het die ekologie losgebreek van sy oorspronklike betekenis as 'n natuurwetenskap en het dit filosofiese en teologiese konnotasies gekry. ' $n$ Mens dink hier byvoorbeeld aan K. Heim, Teilhard de Chardin en G. Altner.

2. Eintlik sou dit eienaardig gewees het as iemand in die RSA so 15, 20 jaar gelede die ekologie as teologiese tema sou aansny, hoewel dit toe alreeds 'n bekende Europese tema was soos dit byvoorbeeld uit $\mathrm{G}$. Altner se boek van 1971, Grammatik der Schöpfung. Theologische Inhalte der Biologie blyk. By ons het die diskussie tussen biologie en teologie tot die evolusietema beperk gebly.

3. Die Suid-Afrikaanse Akademie het wel in 1974 die tema van die ekologie aangesny. Merkwaardig was dat die referente vier natuurwetenskaplikes (A.P. Burger, G.C. Cillié, W.L. Grant en W.A. Verbeek) was en één ekonoom (J.L. Sadie)." By dié jaarvergadering het vier teoloë (B.J. Engelbrecht, F.C. Fensham, B.C. Lategan en T. van der Walt) ook gepraat, maar die Akademie het hierdie teologie-referate nié by die ander laat aansluit nie. Ons het oor ' $n$ ander belangrike tema gepraat, naamlik Die moderne mens en die Bybel, Pretoria, 1974.

4. Toe J.A. Loader vir die RGN aan die einde van 1985 verslag doen oor die stand van navorsing onder andere in die sistematiese teologie, ${ }^{2)}$ stel hy dat een van die temas wat weinig of geen aandag kry nie lób nie in die Christelike Etiek nie), die ekologie is. Ek is daarom in my skik dat een van my doktoraal-studente, J. Buitendag, wat ook lank onder die sistematiese teoloog van Erlangen, naamlik Friedrich Mildenberger, navorsing gedoen het, binnekort onder my sal promoveer met ' $n$ proef- 
skrif getitel Skepping en Ekologie. 'n Sistematiese Ondersoek na die teologiese verstaan van die werklikheid, Pretoria 1985. Oor hierdie proefskrif praat ons later weer.

5. Die meeste Engelse en Afrikaanse woordeboeke wat ek geraadpleeg het, verstaan onder ekologie die studie van "the relations between animals and plants and their environment". "Hoewel sommige in plaas van "diere en plante" van "organismes" of "lewende wesens" praat, lyk dit tog baie waarskynlik dat die mens hierby ingesluit is. Miskien is één rede hiervoor dat die antropologie van die westerse, tegnokratiese mens, die mens eerder sien as die onderwerper, die veranderaar, die ontwikkelaar van "die natuur", as die heerser daaroor deur middel van sy tegniese kennis en "kunnen" en nie soseer as deel van die natuur (of skepping) nie. Vir die afgelope 25 jaar lees ek elke maand die conservation-rubrieke van die drie groot, nasionale buitelewe tydskrifte van die VSA, naamlik Field and Stream, Outdoor Life en Sports Afie/d. Hulle het dit heel dikwels teen die ontwikkelaars look die Army Corpse of Engineers) wat "die natuur" onnodig in die naam van menslike vooruitgang verander en dikwels skend en sodoende visvang-geleenthede, jag-. ontspanningsgeleenthede belemmer en die bekende landskappe se natuurskoon skend en dikwels sekere spesies, plante en diere bedreig en selfs vernietigl Heel selde is die mens as stuk van die natuur (skepping) hierby betrokke as die bedreigde. En hier lê myns insiens die grond vir die gebrek aan teologiese belangstelling in die ekologie. Die mens is as't ware 'n buitestander ten opsigte van die bedreigde natuur en daarom duik daar nóg etiese, nóg religieuse vrae en verhoudinge op; etiek en religie kom net daar ter sprake, waar die mens ter sprake kom. In 'n sekere sin kan ons sê dat etiek en religie tipies menslik is; afgesny van die mens kan dinge of diere nie eties of religieus wees nie.

6. Buitendag kom ${ }^{4}$ ) langs 'n ander weg, naamlik 'n sistematies-teologiese ondersoek, tot dieselfde konklusie, naamlik dat die mens ten opsigte van die ekologie as 'n buitestander gesien word. Sy ondersoek sluit vyf modelle van teologiese refleksie oor die werklikheid in, naamlik die fisiko-teologiese model van $\mathrm{K}$. Heim, die eksistens-teologie model van F. Gogarten, die onto-teologiese model van K. Barth, die eskato-teologiese model van J. Moltmann en die etico-teologiese model van $\mathrm{G}$. Altner. Hy kom tot die konklusie dat elkeen van hierdie teoloë in hulle denk-modelle 'n reuse bydrae tot ons teologiese werklikheidsverstaan lewer, maar dat die gemeenskaplike basiese kritiek teen elkeen is, dat elkeen die "Kartesiaanse dualisme van gees (mens) teenoor natuur (res van skepping)", van subjek teenoor objek, bly handhaaf. Sy voorstel is dat 'n 
moontlike "weg na 'n teologie van die natuur" êrens "tussen 'n dualisme en monisme" geleë is ${ }^{5}$.

7. Ek het dieselfde dualisme tussen mens en natuur gevind by die sg. "skenders" of "vernietigers" of "ontwikkelaars" in hulle antwoord teenoor die "bewaringsmense". Hulle stel dat die mens, sy lewe, waardes, kultuur en beskawing só eksentries ten opsigte van die natuur is, dat indien humaniteitseise en beskawingsdruk dit vereis, die natuur verander, gebruik en selfs verbruik en opgeoffer kan en moet word ter wille van menslike vooruitgang, hoër lewensstandaarde en 'n beter lewenskwaliteit van die mens. Vanweë die status van die mens en sy lewe, was dit altyd, sê hulle byvoorbeeld geoorloof om te jag vir kos (en selfs vir genot!) en om byvoorbeeld mediese eksperimente met diere uit te voer.

8. Ek moet toegee dat die "bewaringsmense" nogal taamlik baie swak punte het:

Eerstens is hulle metodes heel dikwels bedenklik. Ons noem slegs twee aspekte:

(i) Ongelukkig protesteer hulle feitlik teen elke verandering van die bestaande natuurlike omgewingstoestand of teen die vervanging van geboue wat absoluut geen historiese waarde het nie. Elke mens (en geslag) dink ook, as ek dit so mag sê, dat hulle lewe as't ware die Nuwejaar van die tyd is en dat die omgewing soos húlle dit van kleins af leer ken het, dié optimum toestand is waarvan die status quo gehandhaaf moet word. In elk geval - omdat hulle so knaend, so dikwels en feitlik oor alles protesteer en hulle proteste en getalle so deursigtig kunsmatig-georganiseerd is, luister niemand meer na hulle nie.

(ii) Ook die inhoud van hulle proteste stel nie hoër waardes as wat ons in punt 7 hierbo van die "ontwikkelaars" gehoor het nie. Dit is gewoonlik die handhawing van die status quo van die natuurlike omgewing en die behoud van bedreigde spesies, plante en diere ter wille van ons en veral van die nages/ag (dit wil sê die mens). Die ontwikkelaars sien dit as sentimenteel en meen dat vooruitgang, ' $n$ hoër lewenspeil en -kwaliteit (ook van die mens) 'n hoër waarde is as dié van die konserwatiste. Hoe absurd die bewaringsmense se strewe in sommige gevalle kan wees, het byvoorbeeld geblyk uit die televisieprogram, Woestyne van die Wêre/d ${ }^{6)}$, waar hulle dit 
betreur het dat groot dele van die VSA se wes-woestyn as't ware in 'n lushof omskep is, hoofsaaklik deur die opdamming van die magtige Colorado-rivier wat lewegewende water en hidroelektriese krag voorsien het. Die oer-woestyn moes darem ongeskonde vir ons en vir die nageslag bewaar gebly het, sê hulle!

9. Nou wil ek graag toegee dat die mens in 'n sekere sin, as geskape na die beeld van God (Gen. 1:26-27) en vanuit sy kultuuropdrag om die tuin te bewerk en op te pas 'n teen-oor posisie ten opsigte van die res van die skepping het. Dit blyk onder andere ook uit Psalms. Die bewaringsmense wys dikwels daarop -

(i) dat daar ook staan dat die mens die tuin moet oppas en

(ii) dat die oorspronklike voedsel-gawe van Gods kant aan die mense én die diere beslis herbivories en nie karnivories was nie ... .

Maar die eintlike bewering wat ons wil maak, is dat nieteenstaande die unieke posisie van die mens ten opsigte van die res van die skepping, die mens tegelykertyd deel van en lotsgebonde met die sg "res van die skepping" is. Dit blyk onder andere uit twee basiese kenmerke van alles wat skepsel is, alles wat geskape is, naamlik:

(a) Kreatuurlikheid en

(b) Verganklikheid.

Wat (a) betref: Enige skepsel, ook die mens, is of word nooit Skepper nie, nooit God nie. Dit is en bly altyd kreatuur, geskapene. Soos Karl Barth dit aan die begin van sy loopbaan gestel het: Ons kan nie by God uitkom deur van die mens met ' $n$ luide stem te praat nie."

Wat (b) betref: Kreatuurlikheid hou (behalwe die eise van afhanklikheidsbesef en gehoorsaamheid teenoor die Skepper) uiteraard sterflikheid, vergangklikheid in. Met 'n sinspeling op Genesis 2:7 stel Genesis 3:19 dat die mens sal "terugkeer na die aarde toe, want daaruit is jy geneem. Stof is jy, en jy sal weer stof word." By al sy uitmuntende gawes wat van hom 'n uit-sondering maak, bly die mens tegelykertyd lotsgebonde met die res van die skepping in sv wondbaarheid en sterflikheid. Hieroor het Van der Leeuw pragtig geskryf: "Der Tod ist ein integrierender Bestandteil des Lebens ...." Selfs "für die Griechen war der Mensch wesenhaft brotos, sterblich, mortalis. Den Menschen gegenüber stehen die Götter, zu deren Wesen es gehört dass sie unsterblich, athanatoi sind oder am-brotoi, immortales. Sie nähren von Ambrosia, Nicht-tod-speise" ${ }^{\prime \prime \prime)}$. 
10. Hoewel die bevolkingsdigtheid laag was en die lewe en lewensbehoeftes baie minder gekompliseerd en minder veeleisend as vandag was, het die lotsgebondenheid van mens en natuur Abraham en Jakob (met sy seuns en hulle gesinne) in tye van hongersnood Egipte-toe gedwing en het die behoefte aan genoegsame Lebensraum Abraham en Lot van mekaar laat skei. Dit is nie my bedoeling om uit die geskiedenis van Israel en/of die omringende groot beskawings aan te toon hoe grondvrugbaarheid, droogtes, water asook ander bodemrykdomme soos minerale en metale intiem verweef was met die menslike geskiedenis, die geskiedenis van individue, volke en nasies nie. Wat ek wel wil beweer, is dat wat deur die loop van die eeue in nuce aanwesig was, het in die naindustriële-revolusie tydperk die wesenlike wedersydse betrokkenheid van die mens en "die res van die skepping" só op die spits gedryf dat die ekologie dringend óók om teologies-etiese besinning gevra het.

11. Hoe sien die hedendaagse ekologiese krisis, waarby nie net die kwessie van die handhawing van 'n menswaardige lewenspeil betrokke is nie, maar selfs die oorlewing van die mens as sodanig, daar uit? Talle werke is daaroor geskryf, maar die genoemde werk van die SA Akademie $^{9 /}$ bevat nie net die basiese beginsels wat in verband met die betrokke saak op die spel is nie, maar ook die relevante gegewens om daarop ' $n$ toekomsskou te baseer. Myns insiens is die volgende van wesenlike belang om die ekologiese krisis (waarop ons telkens gesinspeel het) te verduidelik:

(a) Die eerste komponent is bevolkingsgroei. Tereg wys Dr A.P. Burger ${ }^{101}$ daarop dat ook bevolkingsgroei indien dit ongehinderd gebeur, eksponensieel van aard is. Hy noem die volgende voorbeeld as illustrasie: Indien Jan van Riebeeck in 1652 een rand teen $5 \%$ enkelvoudige rente belê het sou dit in 1974 (ongeveer 320 jaar later met die Akademiejaarvergadering) R16 wees. Indien die rentekoers $5 \%$ was maar samegesteld, dan sou sy rente toe $\mathrm{R} 6$ miljoen beloop het. Laasgenoemde is ' $n$ voorbeeld van eksponensiële groei. Volgens $A$. Wilsenach in die jongste bulletin van die AfrikaInstituut van $S^{11}{ }^{11}$ is die geboortekoers in Afrika 45 per 1000 per jaar en die sterftesyfer 16 per 1000 per jaar wat beteken dat die Afrika-bevolking elke 24 jaar sal verdubbel. Wanneer dit by klein getalle kom, is so ' $n$ verdubbeling nie so erg nie, maar as dit by miljoene kom, is dit ontstellend. Volgens Wilsenach is Afrika se totale bevolking 531000000 . Dit beteken dat in die jaar 2000 sal dit 851000000 wees (dit wil sê 324000000 monde meer om te voed en 9 jaar later 531000000 mense meer in Afrika alleen om te voed en te versorg). Die wêreldbevolking (waarby Afrika ingesluit) se 
groei is 1,7 persent per jaar en sonder Afrika baie laer; Afrika alleen vermeerder met 2,9 persent per jaar. Tans is die wêreldbevolking 4762000000 en teen die jaar 2000 sal dit 6250000000 wees, dit wil sê byna een-en-' $n$-half-duisend miljoen meer .... Nou sou dié feit nie so ontstellend wees indien die aarde oor onbeperkte hulpbronne beskik het nie, soos landbougrond, wyding en water om kos te verskaf; metale en minerale; energiebronne vir vervoer, en byvoorbeeld krag om te kook, hitte te verskaf, lig te gee en goedere te vervaardig, ens. ens. Maar ongelukkig is dit nie so nie en dit bring ons by die tweede komponent van die ekologie-krisis, naamlik:

(b) Die uitputting en verbruik van die aarde se hulpbronne. Kom ons let op (i) die voedselproduksiebronne en (ii) onhernubare energiebronne.

Oor punt (i): Peter B. Moore ${ }^{12)}$ het deur ingewikkelde wetenskaplike toetse en analises aangedui dat alreeds die prehistoriese mens vanaf die jaar 7000 v.C. maar veral vanaf die Neolitiese tydperk (vanaf 5000 v.C.) die westelike dele van Skotland begin ontbos het vir boerdery en vanaf 5000 v.C. vir veeboerderye, iets wat vanaf die Midde-Ooste na Brittanje versprei het. Daar was tussenstappe, maar uiteindelik is groot areas oorgeneem deur "sphagnum moss, a plant which traps so much water in its large leaf cells that moss effectively drowns competition." Hierdie wurg-mos ontbind stadig en vorm moerasturf "insulating the bog surface from underlying soil nutrients." Die gevolg is groot stukke grond "too wet to farm and not wet enough to support significant populations of fish and waterfowis"', 'n ware moeraswoestyn. Tereg sê George Reiger: ${ }^{13)}$ Natuurlik het die primitiewe boere nie besef wat die gevolge van hulle dade is nie; ons besef dit, en tog is dit so dat "pulp and paper companies push deeper into the boreal wildernesses of North America and Europe, cutting woods that may never regenerate once the sphagnum moss cycle ... begins". Al antwoord wat "the multinational business community" en politici (selfs Ronald Reagan) gee, is dat niks mag staan in die weg van mense "to develop their full potential." Die mens is hier dus weer ek-sentries ten opsigte van die natuur en sy vryheid en welvaart is die hoogste waarde. Die oë word egter gesluit vir die feit dat hier eens-en-vir-altyd onhernubare bronne opverbruik word. Ek het êrens ook gelees dat die $15 \mathrm{~cm}$ vrugbare landbougrond van die VSA wat daar was toe hulle intensief met gewasse begin boer het en wat oor millennia gevorm is, tans slegs $5 \mathrm{~cm}$ dik is. En dit is te verstane, 
want miljarde ton graan, vrugte en so meer word uit die grond geneem en opverbruik, binnelands en deur die buiteland sonder dat vrugbare grond teruggesit word.

En nou noem ek hierdie historiese voorbeeld omdat beide die opverbruik-proses en die antwoord dat niks in die weg van "the people" moet staan "to develop their full potential", tipies van die huidige ekologiese krisis is. Dit sal ons te vér voer om die antropoloog, Marvin Harris, se wiskundige formule om in ' $n$ bepaalde gebied ("society") die verhouding noukeurig vas te stel tussen die kalorië (in die RSA-kilojoules) wat verbruik is om voedsel te produseer, én dié voedsel se kalorië. Dit is vir enigeen duidelik dat indien die verhouding een-tot-een is, die hele poging eintlik futiel is en dat daar dan niks oorbly om byvoorbeeld ontspanning en die kunste te steun nie. Ons dink dikwels dat ons moderne landboumetodes uiters effektief is. Tog het Harris ${ }^{14}$ gevind dat 'n "huntinggathering society" in 'n semi-woestynland in Suidelike Afrika se inset-uitset verhouding 1 tot 9,5 is; skaap- en bokboere in Tunisië se "techno-environmental efficiency" is 1 tot 6, maar in die VSA se beesboer-bedryf neem dit 22000 kalorië menslike arbeid om 270 kalorië voedsel (vleis en vet) te produseer. En in hierdie konteks is dit verder belangrik om te weet dat die VSA, wat maar $1 / 16$ de van die wêreldbevolking uitmaak, per jaar $1 / 3$ de van die hulpbronne wat in dié jaar vir voedselproduksie aangewend word, gebruik, terwyl die res van die wêreld, dit wil sê die 15/16 slegs twee derdes gebruik. Hoewel ek nie nou alreeds kommentaar wil lewer nie, kan 'n mens tog vra: Is hierdie VSA-spandabelrigheid werklik verantwoord en sal die res van wêreld, wanneer dinge begin knyp (en dit sal binne 'n paar jaar sonder twyfel gebeur!) nie ontnugter met die Amerikaners en hulle spreuke van gelyke geleenthede, raak nie? Ook raak ons nie hier aan die probleme van die opneem van waardevolle landbougrond vir bou- en nywerheidsdoeleindes nie.

Oor punt (ii): Dit het hierbo alreeds duidelik begin word dat dit noodsaaklik is om te onderskei tussen hernubare en onhernubare produksie- en energiebronne. Hernubare energiebronne len daaroor handel ons noul is dié bronne wat in miljoene jare nie opgebruik kan word nie, soos sonenergie, windenergie, waterenergie (wat vandag veral vir die opwekking van elektrisiteit gebruik word) én see-energie (soos die golfbewegings wat hoofsaaklik deur die aantrekkingskrag van die maan en die wind veroorsaak word). Teoreties het dié bronne ook wel 'n einde, maar prakties is hul potensiaal oneindig. Daarom is dit ' $n$ vraag of kort-termyn plante (soos sonneblom, mielies en suikerriet) of langer-termyn plante 
(soos hout-produserende bome) ' $n$ hernubare energiebron is wanneer hulle omgesit word in byvoorbeeld diesel of petrol. Hulle kan hernu word, maar put tog die grond uit. Die vraag is dus: Hoe lank kan 'n mens aanhou om sulke energiebronne te hernu en te verbruik? In elk geval, onhernubare energiebronne is hoofsaaklik fossielbrandstowwe (steenkool, aardgasse en aardolies; laasgenoemde is ná raffinering veral as petrol, dieselbrandstof en smeerolies bekend). Kernbrandstof is ' $n$ alternatiewe energiebron, maar dit is eerstens bók beperk wat hoeveelheid betref en tweedens word dit netsoos fosielbrandstowwe opverbruik en dan is dit klaarl Nee, eintlik is dit nie klaar nie, want die verbrandingsprodukte van fossiel-brandstowwe (gasse en sure) én van kernbrandstof (radio-aktiewe kernafval) lewer besoedelingsprobleme wat die lewe van plante, insekte en diere, maar ook en veral van die mens wesenlik bedreig.

(c) Daarom is die derde integrale komponent van die ekologiese krisis die saak van besoedeling wat die mens ten nouste raak: eerstens as aktiewe besoedelaar en tweedens as lydende party in die besoedelingsproses.

(i) Lugbesoedeling is hoofsaaklik afkomstig van nywerhede waar fossiel-brandstowwe gebruik word (ook by die Sasolaanlegte), van binnebrand-motore se uitlaatgasse, van huishoudings waar fossielbrandstowwe en hout verbrand word en van bos- en veldbrande. Laasgenoemde het behalwe omgewingsbeskadiging ook geldelike verliese tot gevolg. Veral die byprodukte van fossiel-brandstowwe se onvolledige verbranding, het eerstens die bekende "suur-reën" tot gevolg wat skadelik is vir die plantelewe (ook landbougewasse) en vir die water, terwyl dit tweedens gesondheidsgevare vir mens en dier inhou wat hierdie lug inasem. Die bekende professor Zerbst het my alreeds in 1971 meegedeel dat mense wat nie rook nie, in Innsbruck waar hy woon, deur die besoedelde lug in te asem presies soveel skadelike stowwe in hulle longe per dag kry as iemand wat 40 sigarette per dag rook. Dan het hierdie besoedeling ook die afbraak van die ionesfeer tot gevolg wat as ' $n$ belangrike skerm dien teen oormatige kosmiese straling en gevolglike kankervorming. Ek weet nie of die elektrifisering van Soweto enige invloed op steenkool verbranding aldaar gehad het nie, maar so vier jaar gelede is op ons plaas in die Hoëveld, $100 \mathrm{~km}$ van Soweto af hoëgraad lugbesoedeling gemeet. 
(ii) Miskien is die mees opvallende vorm van besoedeling water-en landbesoedeling. 'n Baie opvallende besoedelstof beide op land en wat water betref, is die polimere (waaronder ook nylon) en wat ons gewoonlik plastiek noem. In die Desembervakansie (1985) het ek met dieplopende kunsaas gemiddeld 11 plastieksakkies per dag uit die water gesleep en in 'n paar bierhouers (met ronde gate vir die bierblik) ook dooie vis gesien wat daarin soos in 'n net verstrik geraak het. Uiters skadelik is die afval-nylonlyn by openbare waterontspanningsoorde. Talle voëls word daarin verstrik en sterf 'n hongerdood. Ongelukkig is plastiek en glas nie bio-afbreekbaar soos byvoorbeeld die ou kardoese nie en vir die huidige lyk dit tog asof dit nie ekonomies is om dit vir hergebruik te prosesseer nie. Plastiekbesoedeling is lastig en onooglik, maar die eintlike besoedelingsprobleem is die chemikalieë en ander nywerheids- en huishoudelike afvalprodukte in ons waters. Die super-waspoeier lewer dikwels hoogs-skadelike byprodukte en nadat gebruikte water gesuiwer is en na ons damme vir hergebruik gekanaliseer word, is hulle hiper-verryk deur baie hoë konsentrasies fosfor en stikstowwe. Hoe kritiek die toestand van die eertydse hengelparadys en mekka van seilbote, Hartbeespoortdam is, blyk uit die artikel van die waternavorser, K.L. Cochrane van 1983 en die opvolgartikel van twee jaar later. ${ }^{15}$ ) Dit is veral die oormaat van fosfor wat tans die verskriklike hoë algbloei ten gevolg het. Hierdie blou-groen alg, Microcystis, veroorsaak suurstof-gebrek in die dieper water, vorm 'n onooglike blou-groen laag op die water, verhinder lig-penetrasie (wat noodsaaklik vir lewe in water is), is toksies en ruik verskriklik wanneer dit droog word. Sekere vissoorte het al uitgesterf soos die inheemse geelvis en die swartbaars, hoewel die 2000 hektaar groot dam tog 375 ton karp, 100 ton baber en 180 ton kurper per jaar aan hengelaars wat die reuk en vuil-word deur alge kan weerstaan. Die water-hiasinte (die plaag was tussen 1970-1976) het die oormaat voedingstowwe en gesuspendeerde stofdeeltjies uit Hartbeespoortdam se water geabsorbeer, maar dit het so 'n digte deksel op die wateroppervlak geplaas dat Hartbeespoortdam biologies byna dood was en van ontspanning op die dam (bote en hengel) was daar geen sprake nie. Cochrane kom tot die volgende gevolgtrekking en maak dit in die artikel op alle water in die RSA van toepassing: ${ }^{16)}$ "There are therefore no easy answers. The basic problem lies in the high population density and industrial development and the poor water supply in the PWV area. Whichever option or options are taken to solve the problem, they will prove expensive." Ons het hier nie eers van die see-water be- 
soedeling gepraat nie, waarby 'n mens ook die dreigende gevaar van oliebesoedeling veral deur tenkskepe in die oog moet hou. Ek het egter ontsettende besoedeling deur onoordeelkundige storting van huishoudelike en nywerheidsafval rondom DurbanAmanzimtoti self gesien en ervaar om nie eens van die nylon-lynbesoedeling by vakansieoorde se hengelplekke te praat nie. Dit is met een woord: skrikwekkend!

(d) Die vierde komponent van die ekologiese krisis kan 'n mens welvaart noem. Vroeër toe slegs weinig adelikes en rykes 'n hoë peil van welvaart geniet het, het byvoorbeeld die vroeërgenoemde komponente van die ekologiese krisis van vandag, naamlik energieverbruik en besoedeling, weinig gepla. Maar met die toenemende nywerheidsontwikkeling en wêreldwye kommunikasie het welvaart as't ware gedemokratiseer geraak. Dit beteken dat nie net die wêreldbevolking met verstommende getalle toeneem nie, maar dat ' $n$ al groter persentasie van hulle wat vroeër met min tevrede was, nou op dieselfde welvaart (wat vroeër weiniges beskore was) aanspraak maak - dikwels sonder om 'n greintjie arbeid of kundigheid by te dra, net omdat hy of sy mens is en die aarde aan die mens behoort! En dikwels sit agter hierdie eise 'n groot stuk politieke filosofie en -belang. Tereg noem prof. J.L. Sadie ${ }^{17)}$ sy bydrae: Bevolkingsgroei en beskawingsdruk (my kursivering).

12. Dit wil vir my voorkom asof ' $n$ mens binne 'n demokratiese bestel en vryemarkstelsel eintlik nie normaalweg welvaart kan reguleer nie. Wyle adv. John Vorster het tydens een van die eerste brandstofkrisisse in die RSA ' $n$ beroep op die bevolking gedoen om minder en stadiger met hulle motors te ry. Maar hy moes, met erkenning van die individu se regte en vryhede, onmiddellik daarna toevoeg: "Maar dit is u geld, waarvoor $\mathrm{u}$ hard gewerk het en wat $\mathrm{u}$ kan bestee soos $\mathrm{u}$ wil. Ek doen maar net 'n beroep!" Die welvaart van 'n bepaalde samelewing op 'n bepaalde tyd hang van baie faktore af soos byvoorbeeld die landbouproduksie in daardie tyd (droogte of gunstige reën), volop werkgeleenthede, nywerheidsproduksie, minerale rykdomme, politieke stabiliteit en die koopkrag van dié land se geld ens.

13. Maar die eerste drie komponente van die ekologiese krisis van vandag ('n hoë bevolkingsgroeikoers, opverbruik van onhernubare energiebronne en die besoedelingsvraagstuk) kan wel beheer word. Burger het egter aangetoon dat dit (volgens die wêreldbekende klub van Rome se Forrester-Meadows-wêreldmodel) nie sal help om net één van genoemde 
komponente, byvoorbeeld bevolkingsgroei, konstant te hou nie. ${ }^{18)}$ "Dit het geblyk dat om die bevolking van 1975 af konstant te hou, geen oplossing bied nie, aangesien die stygende nywerheidsproduksie tog maar tot uitputting van die hulpbronne lei en dus tot die ineenstorting van die nywerheid, voedselproduksie en dienste". Hierdie totale ineenstorting van veral die westerse leefwyse soos ons hom vandag ken, lyk volgens berekeninge teen $2100 \mathrm{n}$.C. onvermydelik te wees, tensy ons al die drie genoemde komponente van die ekologiese krisis gelyktydig effektief beheer. Dit wil vir my voorkom asof vanweë die uitgestrektheid van ons land, lugbesoedeling 'n tweede plek inneem en dat ons eintlike probleem (vanweë die RSA se varswater tekort) waterbesoedeling is. Behalwe die genoemde artikel van Cochrane, kan ons vir beide die waterbesoedelingsprobleem én die bekamping daarvan verwys na Publico, September $1985^{19}$, waar aangetoon word dat slegs om Hartbeespoortdam se alge te bekamp vanweë die eutrofikasie (oorverryking) deur fosfate en nitrate dit jaarliks sowat R50 000 kos. Dan is daar nog nie eens gepraat van die bekamping van die mineralisasieprobleem (toename van chemiese stowwe, veral soute in die water) wat baie duurder as die eersgenoemde is nie. Om Hartbeespoortdam enigsins leefbaar suiwer te kry van fosfate en nitrate sal tussen 40 en 50 jaar duur. Teen die jaar 2000 sal water in die RSA goud werd wees.

14. Drie sake staan vas:

(a) Die genoemde "ineenstorting", wêreldwyd én in die RSA, is onafwendbaar indien daar nie van nou af aan drastiese beheermaatreëls geïnisieer word nie;

(b) hierdie ineenstorting sal, indien dit plaasvind, die lewensstandaard op aarde, die genoemde welvaart, tot feitlik 'n nulpunt verlaag, tot 'n feitlik onmenswaardige bestaanswyse en

(c) omdat dit hier gaan om God se skepping en veral oor die méns (sy oorlewing, sy waardes en menswaardige bestaan), daarom is die teologie ten nouste by hierdie ekologiese krisis betrokke.

15. Dit is nie my bedoeling om hier uitvoerig uit te stippel wat die teologie vanuit Gods Woord in hierdie verband moet sê en in praksis moet omsit nie. Ek noem slegs 'n paar temas waaroor die teologie van nou af aan én voortdurend in die toekoms sal moet besin in die lig van die huidige en veral toekomstige gevaar:

(a) Die teologie sal weer eens daaroor moet besin wat dit beteken dat 
wat ons "die natuur" of "die wêreld" noem, God se skepping is. Onder sy skepping verstaan ons in hierdie verband die aarde met sy voedselbronne, sy fauna en flora, sy metale en minerale, sy water en sy lug asook die see waarin baie van hierdie genoemde rykdomme en hulpbronne ook aanwesig is.

(b) In noue verwantskap hiermee sal die teologie moet besin oor die plek van die mens binne die Skepping van God. Ons sal moet besin oor die uitsonderingsposisie van die mens ten opsigte van "die res van die skepping", maar ook as integrale deel daarvan, lotsgebonde daarmee. Hier duik vrae op wat in noue verband staan met die saak van die sg. energiekrisis, dit wil sê die opverbruik van onhernubare en beperkte energiebronne:

(i) Is die mens alleen verbruiker of verantwoordelike gebruiker? Mag hy maar verbruik "to develop his fullest potential" (pres. Reagan) of moet daar in die naam van die toekoms van die mens se lewe op aarde, op 'n sekere punt halt geroep word. Al sou ons die vraag teoreties kon oplos van wat "verantwoordelike gebruik" beteken, dan bly die praktiese probleem nog staan: Wie besit die mag en die moed om halt te roep? Dit is duidelik dat dit ' $n$ internasionale poging sal moet wees, want dit help nie dat daar in een of meer lande halt geroep of gerantsoeneer word, en die res van die wêreld gaan maar vrolik voort om te verbruik sonder om oor die toekoms bekommerd te wees nie.

(ii) In verband met hierdie verbruikersvermindering van genoemde energiebronne, is die vraag na gelykheid en billikheid (miskien lê albei betekenisse in "equity"). Is dit billik dat die VSA (1/16de van die wêreldbevolking) $1 / 3$ de van die voedselproduksie- en onhernubare energiebronne gebruik? Hoe sal die afbring van hierdie verbruik (én lewensstandaard bv in die VSA) gemeganiseer kan word en hoe sal dit wêreldwyd ge-egaliseer kan word?

(iii) Voorstanders van die opverbruiksdenke en -praktyk, die "development of man's fullest potential", kan aanvaar dat die tegnologie wel nuwe energiebronne sal vind (bv kernsplitsing en -versmelting). Behalwe dat ook dié bronne beperk en onhernubaar is, al is dit op die lang termyn, het dit vroeër duidelik geblyk dat dit nog geensins die ekologiese krisis sal afweer as die ander twee komponente (bevolkingstoename én besoedeling) nie eweneens en eweveel getem en beheer word nie. Daarom sal die teologie ook aandag moet gee aan: 
(c) Die bevolkingsaanwasprobleem. Dat die bevolkingsgroeikoersprobleem aandag moet kry om die ekologiese krisis af te weer, is duidelik. Burger het dit, in genoemde hoofstuk onweerlegbaar aangetoon. Nou is dit so dat in sommige Europese lande soos Frankryk, die bevolkingsgetal taamlik konstant bly (dit wil sê $0 \%$ groeikoers het). Ook in Nederland is dit aan't daal, ook omdat die lande waarna Nederland sy oorproduksie van mense uitgevoer het, stadig begin vol word. In hoogs-beskaafde gemeenskappe met 'n hoë welvaartpeil, is die groeikoers laag. Maar in die sg. Derde Wêreld is dit ontsettend hoog, dikwels nieteenstaande ' $n$ hoë sterfpersentasie. Wilsenach het in die genoemde artikel aangetoon dat die swart mense in Afrika so 'n hoë groeikoers het, omdat dit saamhang met hulle filosofie, hulle lewens- en wêreldbeskouing. Een element daarvan is dat baie kinders mag, sekuriteit en (merkwaardig genoeg!) "rykdom" beteken. Ook is hulle doodsbeskouing en -ervaring - byvoorbeeld deur hongersnood (volgens my na baie gesprekke met hulle daaroor) - heeltemal anders as die westerse beskawing s'n waarby die uniekheid van die individu ' $n$ groot rol speel. F.J. Engelbrecht ${ }^{20}$ het onteenseglik aangetoon dat toekomsbekommernis en toekomsvoorsorg baie min by die swart mense voorkom of ' $n$ rol in hulle lewe speel.

Die teologiese probleme in hierdie verband is:

(i) Kan ons 'n differensiële groeikoers vir verskillende wêrelddele goedpraat of selfs binne één land (byvoorbeeld blankes $3 \%$ per jaar en swartes $1 \%$ om te sorg dat die blankes nie ondergeploeg word nie!)? Dit lyk vir my net Bybels-verantwoord as ons vir almal (dwarsoor die wêreld) één en dieselfde groeikoers voorstel.

(ii) Verder: Hoe staan dit met die Bybelse vryheidsbegrip rondom die huwelik en kinderverwekking om dié persentasie af te dwing byvoorbeeld deur chemiese middels of operasies selfs teen die wil van die individu?

(iii) Die teologie sal ook moet besin oor die christelik-etiese implikasies van geboortebeperking as sodanig én oor die wyses van geboortebeperking. Kastrasie, aborsie en middels wat die swangerskap baie gou ná (moontlike) ontvangenis beëindig, lyk vir my Bybels-eties ongeoorloof, terwyl die voorkomende "pil" en meganiese middele vir my weer in die lig van die Bybel geoorloof is.

(iv) Maar ook ná geboorte (al is dit onbeheersd) mag ons myns insiens 
nie op 'n hoë sterftesyfer (byvoorbeeld deur honger, siektes as gevolg van onhigiëniese toestande, gebrek aan mediese dienste, moedswillige verwaarlosing ens) staatmaak en goedpraat om op sekere plekke en onder sekere mense die bevolkingsgroeipersentasie laag te hou nie.

(d) Die besoedelingsgevaar is die derde komponent van die ekologiese krisis wat beheer moet word indien die mens wil oorleef of ten minste menswaardig wil oorleef.

(i) Weer eens duik die probleem van die mens as verbruiker van die sg. "natuur" hier op. Die vraag is: Het "die natuur" as sodanig, selfs los van die mens gesien, nie vanuit Bybelse perspektief, as deel van God se skepping, ' $n$ eiewaarde nie? Die mens kan tog nie soos die dief wees om die skape te steel, te slag en uit te roei (te verwoes $1933 \mathrm{ABV}$ ) nie (Joh 10:10).

(ii) Dit lyk vir my asof die taak van die teologie en kerk in hierdie verband sal wees om die lewens- en wêreldbeskouing van die mens weer om te buig vanaf welvaartsmens tot spaarsame mens, van dit wat luuks is, tot die aanvaarding van wat nodig is, van opverbruikersmens tot 'n mens wat verantwoordelik gebruik en selfs bewaar. Die teologie en kerk sal ook saam moet help soek na oplossings om weggooi-produkte (veral houers en verpakkingsmateriaal) wat nie bio-afbreekbaar is nie deur die vervaardigers en verspreiders tot ' $n$ minimum te beperk. Hersirkulering, selfs van afvalprodukte, moet ' $n$ motto wees (in Engels recycling). Die hiperverryking en mineralisasie van water deur die nywerheid (terwyl die huishoudelike verbruiker ook sy deel bydra) sal bekamp moet word saam met lugbesoedeling. Dit sal twee dinge meebring: Hoër pryse (en bygevolg verlaging van lewensstandaard) en minder winste vir die nywerheid en sakesektor. Indien dit nie gebeur nie, lyk die geleidelike ineenstorting (wat vroeër genoem en beskryf is) onafwendbaar, met die gevolg dat die mens, sy lewensruimte, sy waardes en sy lewenskwaliteit onherroeplik en onherstelbaar verlaag sal word.

\section{VERWYSINGS}

1. A.P. Burger e.a., Die mens en sy beperkte hulpbronne, Pretoria 1974.

2. J.A. Loader, Navorsingsbulletin van die RGN. Vol 14/10, (1985), 33.

3. Collins New English Dictionary, CNA - South Africa 1956. 
4. Vgl. a.w., bv. $338-352$ en $371-372$.

5. Vgl. a.w., 338.

6. SAUK, TV 1, Sondag 5 Januarie 1986, 12h50.

7. By J. Arundel Chapman, The Theology of Karl Barth, London 1931, 15.

8. Gerardus van der Leeuw, Unsterblichkeit, Zurich 1950, 183-184.

9. Vgl, Burger e.a., a.w.

10. Burger, a.w., 3.

11. André Wilsenach, "Afrika nie ryp vir Bevolkingsbeheer," Bulletin van die Afrika Instituut van SA, Vol 25, Nommers 8 en 10.

12. Peter B. Moore, "Beneath the Blanket Bogs of Britain," in Natural History 1982.

13. George Reiger, "A Little Knowledge," Field and Stream. Vol 88, nr 12 (April 1983), $49-50$.

14. Reiger, a.w., 50 .

15. K.L. Cochrane, "Hartbeespoortdam: Are the Fish Surviving?", Stywe Lyne/Tight Lines, (Augustus 1983) en "The present and future condition of Hartbeespoortdam as angling ressort", Stywe Lyne/Tight Lines, (November 1985). Cochrane is navorser by die Instituut vir Waternavorsing van die WNNR.

16. A.w. $1985,57$.

17. In Burger, a.w., $21-32$.

18. Burger, a.w., 9 .

19. Karin Pelser, "Bron van alle lewe", Publico vol 5/4 (Desember 1985) (Hidrologiese Navorsingsinstituut, Kommissie vir Administrasie).

20. F.J. Engelbrecht, Tyd en Ruimte by die Bantoe, Pretoria 1973. 